\title{
Book Review The God Gene
}

Book Review of

The God Gene: How Faith is Hardwired into Our Gene, by Dean Hammer, (2004) Doubleday, New York, USA, pp. 241.

George Orwell's book 1984 has all the people doing a daily five minute hate program to exercise their hatefulness. Such would be welcome compared to what we have now from Hollywood, the major networks and books like this. Perhaps I protest too much, but The God Gene is dishonest in that the book describes an instinctual genetic basis for meditation and reflection states which the author calls "spirituality" admitting overtly that such is neither "God" nor "religion. " Some feeble association of this type of "spirituality" with churchgoers is described but there is nothing firm about it. Thus the use of the word "God" is a transparent public relations advertisement promotional ploy -- basically dishonest.

The author does not accept "God" but instead "spirituality" meaning "meditation" as a genetic instinct associated with the discovery of a specific individual gene identified with vaguely described self-transcendent scale of spirituality from a Roman Catholic researcher named Cloninger. Not to give details of this self-transcendent scale on which he relies so heavily is frustrating. I had to do a crash literature search and believe it is safe in saying that this self-transcendent scale has very little to do with the divine transcendentals (matter, identity, truth, oneness, good and beauty). The self-transcendent scale has to do with the dereistic feel-good self-hypnosis which the so-called scientist unscientifically alludes to be an identification with God.

Furthermore, Hammer gets into the "meme" business -- identified as "self-replicating units of culture, ideas that are passed on from one individual to another through writing, speech, ritual and imitation" (Pg. 13). Philosophically, the "meme" is nothing more than a "construct" artificially labeled "scientific" so that it is palatable to non-believers and unphilosophical (unscientific, actually) donuts who have neither beginning, end nor middle. The artifice is that memes and genes sound alike. How clever. And this from scientists?

Essentially, Hammer claims to identify genotypes which are associated with "spiritual" activities as meditation. That the brain would have an area for such could be confirmation of theological relevance because revelation needs Scripture which requires a brain reflecting on reflection (consciousness squared $\mathrm{C}^{2}$ ) [1]. The ability to focus more deeply in ecstatic, self hypnotic, self emergence could be the neuropsychological accompaniment of "religion" as well as "spirituality. "Indeed, Latin (as the highest angelic hierarchy') [2] requires a definite understanding which goes beyond the superficial also. That brain areas are found to exist linked to genes for dereistic meditation ("spirituality") would seem important (although perhaps it may he more important to find the genes for bizarre beliefs, lying, and just plain obstinant malevolence -- no doubt studies of journalists, scientists and mullahs would be very productive).

The book is worshipless, without decent intellection, without

\author{
Perspective \\ Special Issue - 2015 \\ Dr. Samuel A Nigro M.D* \\ Retired, Assistant Clinical Professor Psychiatry, Case Western \\ Reserve University School of Medicine, USA \\ *Corresponding author: Dr. Samuel A Nigro M.D, Retired, \\ Assistant Clinical Professor Psychiatry, Case Western Reserve \\ University School of Medicine, 2517 Guilford Road, Cleveland \\ Heights, Ohio 44118, USA, Tel: 216 932-0575; Email: sam@ \\ docnigro.com
}

Received: August 19, 2015 | Published: October 06, 2015

reason, without revelation, without consciousness squared $\left(C^{2}\right)$, without inspirational stories to create imagination, and without metaphysical engagement. He has no Apostle's Creed and is basically theophobic, intellectually dishonest, believing that a moaning phoneme circus is "spirituality." Hammer seems to offer a genotype of self-delusional meaningless dreaming which is basically nature worship...It fits! On the positive side, Hammer confirms that the brain processes religion.

That he still harps about the Church's treatment of Galileo reveals him to be unhistorical also. Galileo never proved that the ocean tides mean heliocentricity (and Galileo's manic, grandiose, blabbing about such was fundamentally antisocial in those days, deserving all the condemnation he received). Hammer's belief in evolution reveals his own genetic spirituality leaves much to be desired (Read my article, "Why Evolutionary Theories are Unbelievable") [3].

Hammer seems to believe that if the crucifix is made out of wood, so is God. He even uses the word serendipity (Pg. 175) in a positive way which, while common, is totally inappropriate for learned men because "serendipity" is the longest standing joke in the world (Coined by Horace Walple, "serendipity" referred to the Three Princes of Serendip in an old collection of folk tales called the Peregrinaggio. The three serendips were the first "three stooges" and the biggest quacks you would never want to run into. The classical story misinterprets "serendipity" as being a "happy finding by chance." The paradigm is that the three princes discovered and determined a mule to be one-eyed because it ate the worst grass on one side of the road rather than the better grass on the other side of the road. But, of course, if the grass was eaten, how do you know it wasn't better to begin with? Years ago I actually ran an ad in a Cleveland newspaper: "Wanted: oneeyed mule for harmless research." All I could find was a one-eyed horse and it always picked the best bowl of grain to eat wherever it was placed.) Hammer and anyone else who uses "serendipity" in a positive way does not know what he is talking about, like an atheist talking about God.

Finally, Hammer's failure to reference Teilhard de Chardin and Stanley Jaki reveal him to be a dilettante rather than an expert in this area of the scientific basis for God. 


\section{References}

1.Nigro SA (2002) The Attainment of Psychological Freedom Social Justice Review. pp. 176-179.
2.Nigro SA (2001) Angels as Words. Pro Eccelesia, p.14.

3. Nigro SA (2004) Why Evolutionary Theories are Unbelievable. The Linacre Quarterly, 71(1): 58-65. 